\title{
3.3 Social Resilience Assessment in Flood-prone Neighborhoods. A Case Study of Two Districts in Behshahr, Iran.
}

\author{
Maliheh Hashemi TilenoI, Anna GePPERT \\ EneC research laboratory, Paris-Sorbonne University
}

\section{Introductions}

In recent years, Iran has experienced catastrophic flood events. Mazandaran Province, located in the southern shore of the Caspian Sea, is one of the most floodprone areas in the country. In particular, the eastern part of Mazandaran is exposed to flood risks due to the permanent rivers as well as a high population density. Despite all of the actions implemented by the authorities and the money invested in them, the number of fatalities still remains high. In this area frequent annual floods cause damage to several urban areas. These damages result in different effects in the formal and informal settlements, the poor and deprived people particularly women and children. The high social vulnerability to hazards and the failure of traditional approaches to risk management indicate a need for approaches that enhance the system's resilience to flooding.

Resilience is considered a relevant approach for risk prevention and mitigation by several researchers (for example, Schelfaut et al., 2011; Adger et al., 2005; CutTer et al., 2010). According to them, resilience serves as guidance for disaster protection, crisis management and damage control. There is a wide range of definitions of resilience and many different approaches to understanding resilience to external shocks and natural hazards (KhaliLI et al., 2015). An analysis of the literature shows that the notion of resilience developed in the 1960s as a function in the field of physics (BARROCA et al., 2013). The term 'resilience' was used to designate the properties of a spring and to describe the stability of the materials and their ability to return to their initial state in 
the face of external shocks. The concept of resilience was enriched when transferred to different scientific disciplines (DAuphiné \& Provitolo, 2007). In the 1960s, with the rise of systemic thinking, resilience entered the field of ecology from where many meanings of the concept have since emerged, and each is rooted in different worldviews and different scientific traditions (DAvoudi et al., 2012).

Resilience to risk is initially defined as the ability to resist, recover or adapt to the consequences of a shock or change (Mitchell \& HARRIS, 2012). However, it is also a polysemic concept that is in danger of becoming a meaningless term because of its overexploitation and ambiguity (ROSE, 2007). One of the factors that cause ambiguity in the discourse on resilience is the root of the word itself, which means "to bounce back" (Chelleri \& OlazABAL, 2012, p. 54). This interpretation, based on the engineering perspective (DAVOUDI et al., 2013), seems to refer to the pre-crisis or "return to normal" conditions (LHOME et al., 2010, p. 13). COAFFeE (2013) specifically defines it as the ability to resist and rebound from a disruptive challenge. From this perspective, resilience interpreted retrospectively in the light of the previous state (FoLKE et al., 2010) prevents any novelty, innovation or transition to new paths of development. This interpretation seems to focus more on robustness against changes than on resilience that can lead to a transformation (ibid.). In order to resolve these ambiguities, the concept of resilience has changed and evolved from simple engineering entities to socio-ecological systems (Brooks \& Davoudi, 2013). "Evolutionary resilience" (Simmie \& Martin, 2010) is the ability to overcome negative shocks and stresses, to adapt and learn to live with changes and uncertainties (Roussy, 2013) and transform the system in response to constraints and deformations (CARPENTER et al., 2005). Accordingly, this approach is important "for the viability of complex systems, including urban systems" (JUN \& CONROY, 2014, p. 905). It refers to the capacity of populations at risk to innovate, to accept modifications (MEDDE, 2012) and to adapt to changing conditions (disturbances) (QuENAULT, 2014). For example, a resilient city facing a flood episode will have a greater capacity to resist and will not sink into disaster but instead recover more quickly and potentially become a better place.

A critical review of the multidisciplinary literature on resilience reveals a lack of a comprehensive theoretical framework for understanding urban resilience and its complexities, and especially concerning the social aspects of resilience (MACLEAN et al., 2013). Social resilience has the potential to be developed into a coherent analytic framework and offers a fresh perspective on climate change challenges (KECK \& SAKDAPOLRAK, 2013).

This paper aims to address this knowledge gap and seeks to develop and analyze the concept of social resilience to floods as a new conceptual framework by answering the following questions: 
1) Which indicators should be developed in order to evaluate social resilience in flood-prone urban areas?

2) Which prerequisite conditions are needed to strengthen social resilience and manage the risk of flooding in the city of Behshahr in Mazandaran Province, Iran?

Section 1 of this paper introduces a brief description of the concept of resilience. In section 2 we offer a scheme for classifying and incorporating various social resilience indicators extracted from different studies. Section 3 focuses on the study area and survey instrument, followed by a statistical analysis of the survey data in section 4 . The summary, conclusions and directions for future research can be found in section 5 .

\section{A new conceptual framework for social resilience to floods}

Social resilience is defined as empowering the social capacities which foster sustainable societal robustness against crises (KeCK \& SAKDAPOLRAK, 2013). This research incorporates interdisciplinary determinants of resilience epistemology from the fields of marketing, ecology, risk management, urban planning and social science into the definition of communities that are socially resilient to floods. The conceptual analysis identified six distinct indicators which composed the theoretical world of social resilience. These indicators, presented in Table 1, are explained in the following subsections.

\section{Place-specific indicators / social vulnerability}

Place-specific indicators provide a more accurate estimate of resilience based on factors that are relevant to community issues (FrAzIER et al., 2013) and depend on the economic and social situation of the community (KHALILI et al., 2015; Frazier et al., 2013).

In this conceptual framework, these indicators are classified according to (1) the demographic profile of communities and their special needs (KHALILI et al., 2015; JHA et al., 2013, DAuphiné \& Provitolo, 2007), such as age, gender and social vulnerability, and (2) cultural models (Dauphiné \& Provitolo, 2007; Couvent, 2010; Bahadur et al., 2013) like religion and behavior.

Taking place-specific indicators into consideration can help improve resilience through more appropriate mitigation and adaptation initiatives (FrAZIER et al., 2013). 
Table 1: Social resilience framework (own compilation)

\begin{tabular}{|c|c|c|c|}
\hline Indicators & \multicolumn{3}{|c|}{ Sub-indicators } \\
\hline \multirow{5}{*}{$\begin{array}{l}\text { Social } \\
\text { capital }\end{array}$} & \multirow{3}{*}{$\begin{array}{l}\text { Social support } \\
\text { (COLBEAU-Justin, 2002; Kaniasty \& } \\
\text { NorRis, 1999; KHaliLi et al., 2015) }\end{array}$} & \multirow{3}{*}{$\begin{array}{l}\text { Social networks, } \\
\text { relationships } \\
\text { (COLEMAN, 1990; JHA } \\
\text { et al., 2012) }\end{array}$} & $\begin{array}{l}\text { Friendship networks } \\
\text { (CORDIS.EUROPA.EU, 2016) }\end{array}$ \\
\hline & & & $\begin{array}{l}\text { Community networks and } \\
\text { reciprocity } \\
\text { (CORDIS.EUROPA.EU, 2016) }\end{array}$ \\
\hline & & & $\begin{array}{l}\text { Formal Networks } \\
\text { (CORDIS.EUROPA.EU, 2016) }\end{array}$ \\
\hline & \multirow{2}{*}{$\begin{array}{l}\text { Place attachment } \\
\text { (KotZEE \& REYERs, 2016; JHA et al., } \\
\text { 2013; CORDIS.EUROPA.EU, 2016; PATON, } \\
\text { 2010; GonZÁLEZ-RIANCHO et al., 2015; } \\
\text { BECKER et al., 2013; LutOFF et al., 2016; } \\
\text { PATON et al., 2001; KHALILI et al., 2015) }\end{array}$} & \multicolumn{2}{|c|}{$\begin{array}{l}\text { Place values } \\
\text { (GonZÁLEZ-RIANCHO ET al., 2015) }\end{array}$} \\
\hline & & \multicolumn{2}{|c|}{$\begin{array}{l}\text { Feeling of belonging } \\
\text { (RATTER \& GEE, 2012) }\end{array}$} \\
\hline \multirow{4}{*}{$\begin{array}{c}\text { Public } \\
\text { awareness }\end{array}$} & $\begin{array}{l}\text { Experience with previous } \\
\text { disasters } \\
\text { (JHA et al., 2012; FrAZIER et al., 2013; } \\
\text { CORDIS.EUROPA.EU, 2016; GONZÁLEZ- } \\
\text { RIANCHO et al., 2015; BECKER et al., } \\
\text { 2013; CUTTER et al., 2010; COLBEAU- } \\
\text { JusTIN, 2002; DAVOUDI et al., 2013; JHA } \\
\text { et al., 2013) }\end{array}$ & \multicolumn{2}{|c|}{ Using local knowledge } \\
\hline & $\begin{array}{l}\text { Education } \\
\text { (BAHADUR et al., 2013; PATON et al., } \\
\text { 2001; JHA et al., 2013; CORDIS.EUROPA. } \\
\text { EU, 2016; KotZEE \& REYERS, 2016; } \\
\text { KHALILI et al., 2015; FraZIEr et al., } \\
\text { 2013; 2010; RouSSY, 2013; DAUPHINÉ } \\
\text { \& ProvitoLO, 2007; YASMIN et al., } \\
\text { 2016) }\end{array}$ & \multicolumn{2}{|c|}{ Continuous and effective learning } \\
\hline & \multirow{2}{*}{$\begin{array}{l}\text { Communication and } \\
\text { information exchange } \\
\text { (SCHELFAUT et al., 2011; JHA et al., } \\
\text { 2013; TRACHSLER, 2009; DAVOUDI } \\
\text { et al., 2013; FraZIER et al., 2013; } \\
\text { CORDIS.EUROPA.EU, 2016; DAUPHINÉ \& } \\
\text { ProvITOLO, 2007; GONZALLEZ-RIANCHO } \\
\text { et al., 2015; KHALILI et al., 2015) }\end{array}$} & \multicolumn{2}{|c|}{$\begin{array}{l}\text { Issuing alerts and communicating emergency } \\
\text { decisions }\end{array}$} \\
\hline & & \multicolumn{2}{|c|}{ Encouraging new forms of social networks } \\
\hline \multirow{7}{*}{$\begin{array}{c}\text { Good } \\
\text { governance }\end{array}$} & \multirow{2}{*}{$\begin{array}{l}\text { Trustfulness } \\
\text { (PATON, 2010; YASMIN et al., 2016; } \\
\text { BECKER etal., 2011; GonzÁLZZ-RAANCHO et } \\
\text { al., 2015; ENEMARK, 2006; TRACHSLER, } \\
\text { 2009) }\end{array}$} & \multicolumn{2}{|c|}{$\begin{array}{l}\text { Transparency } \\
\text { (FRIEND et al., 2014) }\end{array}$} \\
\hline & & \multicolumn{2}{|c|}{$\begin{array}{l}\text { Equity } \\
\text { (CoRDIS.EUROPA.EU, 2016; BAHADUR et al., 2013; GoNZÁLEZ- } \\
\text { RIANCHO et al., 2015) }\end{array}$} \\
\hline & \multirow{2}{*}{$\begin{array}{l}\text { Leadership effectiveness } \\
\text { (HARLAND et al., 2005; HEGNEY et al., } \\
\text { 2008; KHALILI et al., 2015; GONZÁLEZ- } \\
\text { RIANCHO et al., 2015) }\end{array}$} & \multicolumn{2}{|c|}{$\begin{array}{l}\text { Responsible authorities } \\
\text { (WHO, 2010) }\end{array}$} \\
\hline & & \multicolumn{2}{|c|}{$\begin{array}{l}\text { Knowledge-based decision-making } \\
\text { (GONZÁLEZ-RIANCHO et al., 2015) }\end{array}$} \\
\hline & \multirow{3}{*}{$\begin{array}{l}\text { Coordination and cooperation } \\
\text { (MILLER et al., 1999; HARLAND et al., } \\
\text { 2005; FORGETTE \& BOENING, 2009; } \\
\text { TRACHSLER, 2009) }\end{array}$} & \multicolumn{2}{|c|}{ Transfer of development rights } \\
\hline & & \multicolumn{2}{|c|}{ Active stakeholder engagement } \\
\hline & & \multicolumn{2}{|c|}{ Collaboration with NGOs and civil society } \\
\hline
\end{tabular}




\begin{tabular}{|c|c|c|}
\hline Indicators & & Sub-indicators \\
\hline \multirow{9}{*}{$\begin{array}{l}\text { Place- } \\
\text { specific } \\
\text { indicators }\end{array}$} & \multirow{7}{*}{$\begin{array}{l}\text { Demographic profile of a } \\
\text { community and special needs } \\
\text { (KHALILI et al., 2015; JHA et al., 2013; } \\
\text { DAUPHINÉ \& PROVITOLO, 2007) }\end{array}$} & $\begin{array}{l}\text { Sex } \\
\text { (Tobin, 1999; CutTer et al., 2010; JHA et al., 2013) }\end{array}$ \\
\hline & & $\begin{array}{l}\text { Age } \\
\text { (Tobin, 1999; Cutter et al., 2010; FraZIER et al., 2013; } \\
\text { Cordis.europa.eu, 2016; JHA et al., 2013) }\end{array}$ \\
\hline & & Ethnicity (CORdis.eURopa.eu, 2016; JHA et al., 2013) \\
\hline & & 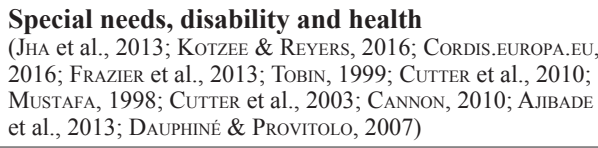 \\
\hline & & $\begin{array}{l}\text { Personality, relational competencies } \\
\text { (ColBEAU-Justin, 2002; LutOFF et al., 2016; JHA et al., 2012) }\end{array}$ \\
\hline & & $\begin{array}{l}\text { Socio-economic status } \\
\text { (Frazier et al., 2013; JHA et al., 2013; ToBIn, 1999; CUTTER } \\
\text { et al., 2010; TERI, 2011; JHA et al., 2012; CORDIS.EUROPA.EU, } \\
\text { 2016; DAUPHINÉ \& Provitolo, 2007) }\end{array}$ \\
\hline & & 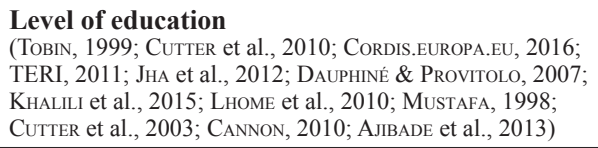 \\
\hline & \multirow[t]{2}{*}{$\begin{array}{l}\text { Cultural models } \\
\text { (DAUPHINÉ \& Provitolo, 2007; } \\
\text { COUVENT, 2010; BAHADUR et al., 2013) }\end{array}$} & 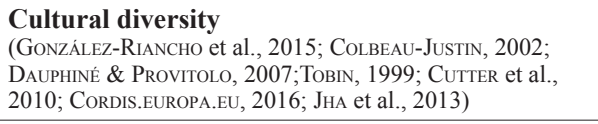 \\
\hline & & Religion \\
\hline \multirow{4}{*}{$\begin{array}{l}\text { Local } \\
\text { autonomous } \\
\text { innovations }\end{array}$} & \multicolumn{2}{|l|}{$\begin{array}{l}\text { Inductive } \\
\text { (BAHADUR \& DoCZI, 2016) }\end{array}$} \\
\hline & \multicolumn{2}{|l|}{$\begin{array}{l}\text { Indigenous } \\
\text { (BAHADUR \& DOCZI, 2016) }\end{array}$} \\
\hline & \multicolumn{2}{|l|}{$\begin{array}{l}\text { Low-cost } \\
\text { (BAHADUR \& DocZI, 2016) }\end{array}$} \\
\hline & \multicolumn{2}{|l|}{$\begin{array}{l}\text { Iterative } \\
\text { (BAHADUR \& DocZI, 2016) }\end{array}$} \\
\hline \multirow{3}{*}{$\begin{array}{l}\text { Self- } \\
\text { organization }\end{array}$} & \multicolumn{2}{|c|}{$\begin{array}{l}\text { Self-reliance, self-efficacy } \\
\text { (DAvoudi et al., 2013; Quenault, 2014; BeCKER et al., 2013; GonZÁlez-RIANCHO et al., 2015; PAton, } \\
\text { 2010; BECKER et al., 2011) }\end{array}$} \\
\hline & \multicolumn{2}{|c|}{$\begin{array}{l}\text { Community efficacy } \\
\text { (PAton et al., 2001; Miller et al., 1999; Harland et al., 2005; Forgette \& BoENING, 2009) }\end{array}$} \\
\hline & \multicolumn{2}{|c|}{$\begin{array}{l}\text { Collective efficacy } \\
\text { (Moore et al., 2004; KHALILI et al., 2015; PATON, 2010; GonZÁLEZ-RiANCHO et al., 2015) }\end{array}$} \\
\hline
\end{tabular}

However, existing models of resilience estimation are less relevant to place-specific indicators, and the lack of attention to local community characteristics can undermine the effectiveness of resource allocation and response measures (BerKe \& GodschalK, 2009; Burby et al., 2000; FrAZIER et al., 2013). 


\section{Demographic profile of the community and special needs}

"Flood events have a disproportionate impact on the poor and socially disadvantaged, particularly women and children" (JHA et al., 2012, p. 20). Inequalities explain why crisis management fails and why it has a very unequal impact on affected populations (Turner et al., 2003; SMit \& WANDEL, 2006; GAllopin, 2006, quoted by ZANinEtTi et al., 2013). The demographic profile of communities, which includes variables such as gender, age, ethnicity, socio-economic status and health, is the basis for the analysis of community vulnerability. For instance, many elderly people have difficulty responding to emergencies due to disability or limited access to information (SATO, 2006). Furthermore, an epidemiological assessment of two areas in Bangladesh that were devastated by the cyclone in 1991 shows that more women than men were killed, partly because they were physically less able to run and because they tried to save their children while putting their own lives at risk (JHA et al., 2012). Therefore, it is very important that decision-makers find an empirical basis for selectively targeting the most vulnerable group and concentrating on places where people are more at risk (MUSTAFA, 1998; Cutter et al., 2003; CAnnon, 2010; Ajibade et al., 2013).

\section{Cultural models}

Aside from the social characteristics of the people, the cultural models like mutual aid traditions, cultural diversity, individual and societal behaviors (GoNZÁLEZ-RiANCHO et al., 2015; Colbeau-Justin, 2002; Dauphiné \& Provitolo, 2007; Cutter et al., 2010; Cordis.europa.eu, 2016; JHA et al., 2013; Tobin, 1999) and religion influence social resilience. For example, the expectation of negative outcomes (refusal / fatalism) or positive outcomes (PATON, 2010; BECKER et al., 2011; BECKER et al., 2013) affects the social reaction and vulnerability in the face of disasters.

\section{Public awareness}

Flood risk awareness is the collective (or individual) risk knowledge of a community exposed to flood risks (CORDIS.EUROPA.EU, 2016). This term is interchangeable with the notions of an informed culture and collective vigilance (HopKINS, 2005). Public awareness targets all people in a society, including decision-makers, educators, professionals, members of the public and people living in exposed areas (UNISDR 2004). Risk awareness can be increased with the following three variables. 


\section{Experience with previous disasters}

At the household and community level, valuable lessons can be drawn from the experience with flooding (JHA et al., 2012). The lessons learned from previous disasters (emphasized by many researchers like Frazier et al., 2013; Cordis.europa.eu, 2016; GonzÁlez-Riancho et al., 2015; Becker et al., 2013; Cutter et al., 2010; ColbeAu-Justin, 2002 and DAvoudi et al., 2013) should be used in the current and future development of risk-prone urban areas (JHA et al., 2013).

\section{Education}

Improving flood risk knowledge (BAhAdur et al., 2013; PAtON et al., 2001; JHA et al., 2013; Cordis.europa.eu, 2016; Kotzee \& Reyers, 2016; Khalili et al., 2015) and developing a culture of risk (LHOME et al., 2010) are needed to promote awareness and acceptance of the various options for protecting a community from being flooded. Education increases the perception of risk in the context of everyday life and awareness raises the intention of a society to make preparations (GONZÁLEZ-RIANCHO et al., 2015).

\section{Communication and information exchange}

Risk communication covers all communication between the various actors at different scales (ScHELFAUT et al., 2011) ranging from scientists to decision-makers and the public (REISI et al., 2014).

A new social scheme seems recommendable that includes the coordination of new forms of social networks, notably by using modern communication technologies (SATO, 2006) to improve communication between authorities, civil society and individuals (TRACHSLER, 2009).

\section{Good governance}

Governance is defined as the decision-making process and the process by which decisions are implemented (or not implemented) (UNESCAP, 2009). The concept of good governance refers to the responsibility of governing bodies to ensure that political, social and economic priorities in decision-making are based on a broad consensus in society (LEGAS, 2016). Three secondary variables of good governance to reinforce social resilience are: (1) trustfulness (PAtON, 2010; YASmin et al., 2016; Becker et al., 2011; GonZÁlez-Riancho et al., 2015; ENEMARK, 2006; TrachSLER, 2009), (2) leadership 
effectiveness (Harland et al., 2005; Hegney et al., 2008; KHAlili et al., 2015; GonZÁlezRiANCHO et al., 2015) and 3) coordination and cooperation (Miller et al., 1999; HARLAND et al., 2005; Forgette \& Boening, 2009; Trachsler, 2009).

\section{Trustfulness}

In risk management, it is necessary to increase a society's confidence in its authorities and management system in order to facilitate the adoption of protective behaviors (GonzÁLEz-RiAncho et al., 2015). Confidence as an essential prerequisite for legitimacy in the context of environmental governance is determined by public perception of the performance and competence of the governing body (TURNER et al., 2016). It is strongly associated with the equity (Cordis.EUROPA.EU, 2016; BAHADUR et al., 2013; GonZÁLEZ-RIANCHO et al., 2015), greater accountability and transparency (FRIEND et al., 2014) of the government in front of residents and actors.

\section{Leadership effectiveness}

Leadership is defined as the process in which one person or a team influences others to achieve a goal and leads the organization in a more homogeneous and coherent manner (Legas, 2016). Leadership and governance ensure that policy and strategic frameworks exist and are associated with effective oversight, consolidation of the stakeholder coalition, regulation and accountability (WHO, 2010). Clarifying the roles of each institution in risk management is important so that society knows what to expect, who is in charge and how to behave in an emergency (GONZÁLEZ-RIANCHO et al., 2015; LuTOFF et al., 2016). Leadership effectiveness is also associated with decision-making and the relevance of knowledge-based policy options (GonZÁlez-Riancho et al., 2015).

\section{Coordination and cooperation}

Achieving the goals of resilience requires the cooperation of all actors (politicians, community and youth groups, civil society, universities, business and others) who run the city on a daily basis (UNISDR, 2013). When local leaders involve citizens in the decision-making process, city resilience is strengthened and more accurately reflects the needs of residents and businesses (ibid). In order to increase institutional support (GONZÁLEZ-RIANCHO et al., 2015), the transformation of development rights and the collaboration with NGOs and civil society are inevitable (FrAZIER et al., 2013).

\section{Social capital}

Social capital as a determinant of community vulnerability and resilience to environmental change and uncertainty (ADGER, 2000; FRANK et al., 2011) has multiple 
analytically distinct dimensions (Alex et al., 2015). Communities with strong social capital and networks are more resilient than those without (MuRPHy, 2007). Indeed, in cultures where community values are strong and a habit of working in a community exists, the response and recovery capacities are more frequent than those of individualistic societies (Colbeau-Justin, 2002). Social capital refers to indicators such as attachment to a place and social support.

\section{Place attachment}

This type of attachment links a place to social relationships through a strong emotional component related to the perceived and intangible values of the place or the "spirit of place" (GonZÁlez-Riancho et al., 2015, p.55). RAtTer and GeE (2012) demonstrate that this sense of belonging encourages people to act and strengthens participatory processes.

\section{Social support}

Social support (from neighbors, family members and relatives) (COLBEAU-JUSTIN, 2002 ) is defined as the social relationships and social norms that make social values and structures robust (BAHADUR et al., 2013). Social support is also based on trust and reciprocity (Enemark, 2006; Pelling \& High, 2005; Nakagawa \& Shaw, 2004; Khalili et al., 2015). Interpersonal relationships as a result of trust and reciprocity develop on the basis of social ties, networks and connections (Pelling \& High, 2005; Alex et al., 2015), which increase solidarity (COUvENT, 2010) and build local alliances and social cohesion (PATON et al., 2001; UNISDR, 2013).

\section{Self-organization}

Self-organization discusses the empowerment of communities and individuals (QuENAUlt, 2014) to adapt by themselves and with their own resources in the face of external challenges (SwANSTROM, 2008). This term, associated with individual responsibility, changes the notion of vulnerable victims into vulnerable culprits (Quenault, 2014). Self-organization develops through the increase of (1) self-reliance (Paton, 2010; Davoudi et al., 2013), personal efficiency and personal responsibility (Becker et al., 2013; GonZÁlez-Riancho et al., 2015; Paton, 2010; Becker et al., 2011), (2) community effectiveness (social responsibility and community belief in their own achievement) (PAton et al., 2001; Miller et al., 1999; Harland et al., 2005; Forgette $\&$ Boening, 2009) and (3) collective effectiveness (a shared conviction among a group 
of people of their collective power to produce specific changes) (Moore et al., 2004; Harland et al., 2005; Kalili et al., 2015; Paton, 2010; GonZÁlez-Riancho et al., 2015). This self-organization of populations without government influence (ROBERT, 2012) through the development of the involved actions and the informal networks (COLBEAUJustin, 2002) allows for a greater flexibility and adaptation to disaster in the long term (Couvent, 2010).

\section{Local autonomous innovations}

Although innovation is considered an important determinant of evolutionary resilience by several scholars (for example, LALONDE, 2011; Khalili et al., 2015; Forgette \& Boening, 2009; Cordis.europa.eu, 2016; Demchak, 2006), it is rarely used by development actors as an idea for increasing resilience (BAHADUR \& DoczI, 2016). These researchers argue that the ability to work with uncertainty can be improved through the promotion of improvisation and innovation. Local autonomous innovations argue that people are treated as a source of ideas, innovations and institutional arrangements (GUPTA, 2013) that transform constraints into opportunities. BAHADUR and DocZI (2016) identify five key characteristics for autonomous innovations. According to them, autonomous innovations are inductive, indigenous, inexpensive, intuitive and iterative. In other words, the term refers to innovations that are organically derived from 'nonexperts' in an endogenous way and without direct external help. Innovations that are simple in nature and inexpensive take into account resource constraints and poverty in low-income communities. They also refer to communities with strong social networks and with a culture that encourages and celebrates creativity and experimentation, the existence of an aspiration despite the scarcity of resources and a favorable political and economic environment. These characteristics enhance innovation as a key to building community resilience.

\section{Methodology}

This study integrates qualitative and quantitative approaches and is centered on exploratory research. To this end, we focused on transdisciplinary studies along three axes: (1) the theory of resilience, (2) risk management and (3) social aspects of crises, in particular flooding, in order to identify and incorporate the most essential social resilience indicators. There is a great diversity among the assessment targets: the inhabitants, the municipality and the responsible organizations. The data sources for this research are individual and group interviews, questionnaires and existing datasets. The field survey starts with open and exploratory questions concerning risk management 
in Behshahr. In order to know who makes decisions and how the different actors work together in a time of crisis the following steps were taken: (i) Four interviews were conducted with two officials from the municipality of Behshahr, (ii) one interview was conducted with the crisis management staff in the governorate and (iii) one interview with a crisis management employee at the Red Crescent in Behshahr. These steps allow us to classify the theoretical and conceptual research framework concerning the issues of the study area that were identified. In the next step, 50 questionnaires were distributed in order to assess social resilience in the case studies. The target statistical population of the research includes the population of the two flooded districts in Iran, who were selected by random among the residents and are aged between 20 and 80 years. In addition to this quantitative study, we conducted in-depth, semi-structured and group interviews with inhabitants for the purpose of clarifying some points. Methodologically speaking, this approach allows them to express themselves freely and to take their time to voice their opinions and feelings.

\section{Study area}

The study area contains the two neighborhoods Koohi-Kheil and Sālār-Zādeh in the city of Behshahr, located on the southern shore of the Caspian Sea in Iran. According to the 2011 population census, Behshahr's population comprises 94,702 inhabitants, of which 47,314 are women and 47,388 men (CSI, 2016). The two largest rivers of

\section{Figure 1: Two flood-prone neighborhoods in the city of Behshahr}

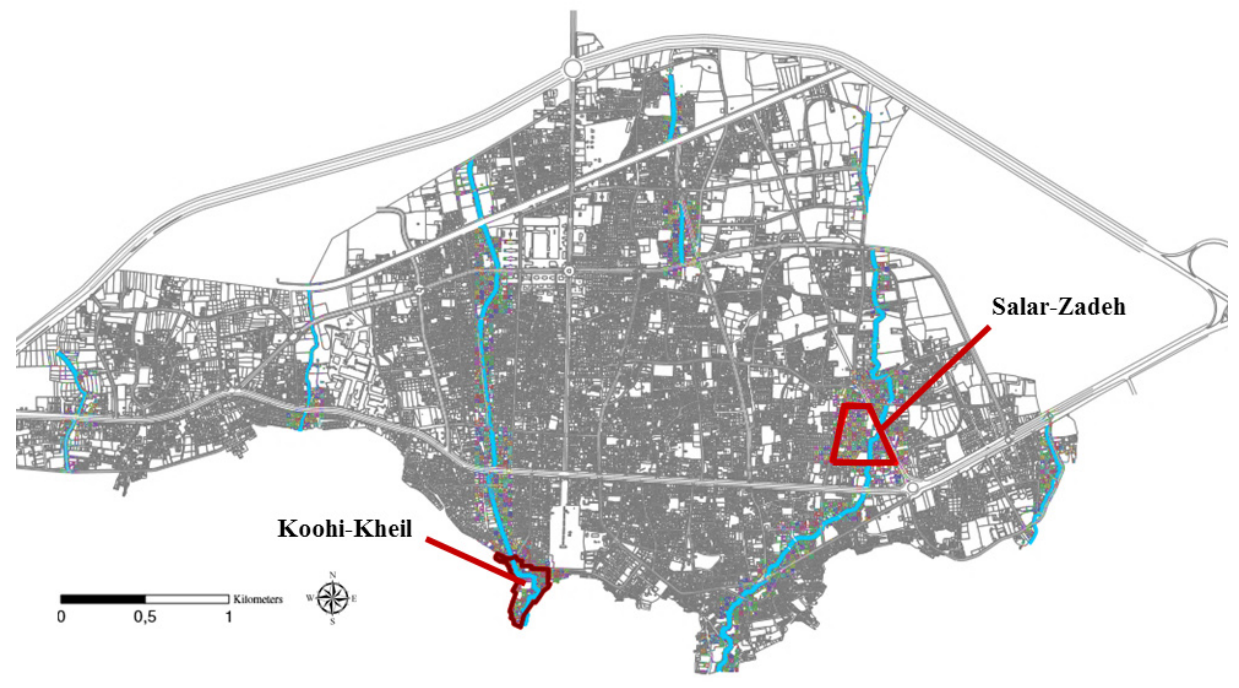


Behshahr are Borzu and Bozpol (BDNRP, 2016). The houses built on the banks of these two rivers such as the in Koohi-Kheil district on the banks of the Borzu River and in the Sālār-Zādeh district along the Bozpol River are exposed to the risk of collapse during the flood, as can be seen from the floods of 2012 and 2013 (see Figure 1). The Koohi-Kheil neighborhood is in the southernmost part of the city on the bank of the Borzu River, which is the closest settlement for the inhabitants of Hezār-Djarib villages living in the heights. This neighborhood was built during the agrarian reforms (1963) and through waves of immigration from the villages to the cities. It is one of the marginal neighborhoods of Behshahr that suffers from socio-economic problems such as unemployment, illegal constructions and declining literacy (BDNRP, 2016). The second study area, Sālār-Zādeh, is one of the formal neighborhoods with more favorable socio-economic conditions. This neighborhood was built between 1981 and 2011 in parallel with Behshahr's industrial growth and has recently grown faster due to rising land prices and massive construction of buildings.

\section{Results and discussion}

In order to evaluate the conceptual framework, we conducted in-depth interviews with officials and residents and distributed the questionnaires. The purpose of this survey is to evaluate the social resilience of these communities considering the integrated indicators introduced above.

\section{Place-specific indicators}

The target statistical population of the research is made up of inhabitants of these two study areas, who were randomly selected and are between 20 and 80 years of age. The interviewees were asked for demographic variables including their age, gender, educational level, employment and marital status. 51\% of the interviewees are men and $49 \%$ are women, $84 \%$ are married and $16 \%$ are single. The results reveal a considerable socio-economic difference between the two neighborhoods. The educational level of the Sālār-Zādeh district is superior to that of the Koohi-Kheil interviewees. Employmentrelated factors also show similar correlations. $61 \%$ of those interviewed in the KoohiKheil neighborhood are unemployed, whereas in the Sālār-Zādeh neighborhood only $17 \%$ are unemployed. The number of household members in the two neighborhoods (including about 4 persons) is similar, and $6 \%$ of the interviewees who are older than 60 live on their own. 


\section{Public awareness}

Public awareness was assessed based on three sub-criteria: experiences with previous disasters, education and information exchange.

\section{Experiences with previous disasters}

"The floods of 2012 and 2014 were the starting point of awareness for both the people and the officials. The country was not ready for the floods. The crisis management organization was built, the administrative and organizational units as well as the people began to wake up..." (Vice-President of Behshahr Municipality, personal interview, April 2016).

As the target statistical population, the inhabitants were asked to name floodplains and recall how many times their neighborhood had been flooded. The results reveal that all of the interviewees in Koohi-Kheil are aware that their neighborhood has been affected by the flood, and almost all of them know where the flooding occurred. In contrast, $11 \%$ of Sālār-Zādeh residents were not aware of the previous floods. Here, the results of the in-depth interviews demonstrate two facts: First, most people who have recently inhabited this area did not know about the past flood experiences. Second, people who had not suffered from the floods could not find out that the neighborhood had been flooded due to a lack of communication.

\section{Education}

A Behshahr municipal employee said people are not well informed. "They add land to the river front to extend their properties. This increases the sinuosity of the river and when the flood arrives, it is the people themselves who become victims" (Behshahr municipal employee, personal interview, April 2016). And according to another official: "Many people do not know that their house is located in the flood zone. Since the floods have not targeted their property for 40 years, they think that the accident will not take place again" (Vice-President of Behshahr Municipality, personal interview, April 2016). The Red Crescent Society is one of the organizations that trains rescue teams. One of the Red Crescent officials told us about the existence of courses organized for schools as well as various offices. He added: " $80 \%$ of our members are volunteers, and before an event takes place, we invite banks, schools and people who want to learn first aid" (personal interview, April 2016). Conversely, none of the interviewees living in the Sālār-Zādeh and Koohi-Kheil districts participated in these courses. $64 \%$ of them are unable to identify safe places for rescue. $83 \%$ of those interviewed in the Sālār-Zādeh neighborhood and $71 \%$ of the Koohi-Kheil residents do not know how to swim. 


\section{Communication and information exchange}

In the event of a flood, the crisis management committee informs the responsible persons. The head of the crisis management committee in Behshahr tells us: "I check the meteorological websites and if there is a forecast for heavy rain or flooding, we make the organizations aware by text messages, telephone calls, post or emails" (personal interview, April 2016).

The Vice-President of Behshahr Municipality explains: “As soon as we keep abreast, we organize the teams on the ground immediately in order to avoid the risks... in the whole region, people have access to radio and television, and the public relations sector of the municipality warns local units and firefighters" (personal interview, April 2016).

Unfortunately, the results show that the majority of people who live in the study areas are not formally informed, which causes more damage. In fact, $37 \%$ of the respondents were made aware through their neighbors and relatives and 35\% of them noticed climate signs such as heavy rainfall or rising water levels. A 70-year-old woman who lives in the Koohi-Kheil district remarks sarcastically: "It is when the water enters the house that we realize the flood is coming" (personal interview, April 2016).

The Red Crescent official relates the tragic story of a woman who became a victim of flooding in the Sālār-Zādeh district: "She didn't know that the water had already massively inundated the street. She opened the door of her house, the waves took her away" (personal interview, April 2016). It seems very necessary indeed to establish an early warning system and share information in order to reduce the vulnerability of these neighborhoods.

\section{Good governance}

Good governance is evaluated with the three variables of trustfulness, leadership effectiveness and coordination.

\section{Trustfulness}

What is clearly observable in the majority of the reports from interviewees who live in these two flood-prone neighborhoods is the lack of people's confidence in institutions. The head of the crisis management committee refers to the historical 
experiences of Iranians which prevent them from having confidence in the state and its organizations. According to him, this mistrust makes cooperation between people and the crisis management committee impossible (personal interview, April 2016).

In the in-depth interviews, the respondents mentioned the lack of sincerity, the segregating behaviors and the empty promises as the cause of their dissatisfaction with municipal and governmental organizations.

\section{Leadership effectiveness}

In order to better evaluate the functions of the city government, we studied the level of satisfaction of the people regarding the tasks performed by the managers. The results of the questionnaires and the in-depth interviews show that in comparison with the Koohi-Kheil district, where some flood mitigation measures like building the river walls have been implemented, interviewees in the Sālār-Zādeh district are less satisfied with the actions taken by the municipality and other organizations in charge and complained about the lack of action to prevent flooding.

A resident of Koohi-Kheil tells us: "The only thing they have done is compensate us financially by giving us a sum with which I was only able to buy a fridge. If the floods are still going to take place, everything will become the same as before" (man, 64 years old).

\section{Coordination and cooperation}

In Behshahr, as far as flooding is concerned, the cooperation between the urban governors is accomplished in the form of the crisis management committee founded after the floods of 2012 under the direction of the governor of Behshahr. This committee contains 22 sectors, including the police, water, electricity, gas production establishment, the Red Crescent and fisheries. The vice-chair of the crisis management committee said that "after each alarm signal, we immediately select and invite the sectors whose presence seems indispensable and we organize the committee" (personal interview, April 2016). We asked him why they do not cooperate with people and NGOs. He explained: "In 2010, we had a forest fire, two of our volunteers were seriously burned, so they come almost once a month and ask us for compensation ... As for the NGOs, we do not ask for their help because they are not covered by social security and therefore the future of their members cannot be assured" (ibid.). 


\section{Social capital}

In this paper, we have analyzed social capital with the help of the indicators of place attachment and social support.

\section{Place attachment}

With the purpose of evaluating the feeling of belonging to the neighborhood, we asked the respondents questions about two factors: the length of stay and their interest in staying in the neighborhood. According to the results, the number of interviewees who have been living in the neighborhoods of Koohi-Kheil and Sālār-Zādeh for more than 15 years was $84 \%$ and $50 \%$ respectively. Thus, the length of residency in Koohi-Kheil is relatively high. Residents were also asked why they continue to live in the flood zone. $50 \%$ of the inhabitants interviewed in Koohi-Kheil talked about the impossibility of settling elsewhere due to livelihood issues and poverty. On the contrary, all interviewees in Sālār-Zādeh said they like their neighborhood and expressed their sense of belonging to their neighborhood and that is why they want to stay. Therefore, although the average length of residency in Sālār-Zādeh is shorter than in Koohi-Kheil, the sense of belonging in the former is considerably higher than it is in the latter neighborhood.

\section{Social support}

In order to assess how the people support each other in the neighborhoods, we asked about the mutual relationships and their sense of solidarity. Some of the questions were: Do you trust your neighbors? Are you aware of the various difficulties your neighbors are facing? Would you be willing to help them?

The results demonstrated that there is a high level of trust among the inhabitants of Koohi-Kheil and a good understanding of the needs of their neighbors. A 67-yearold woman in Koohi-Kheil said: “....after the flood, when local distribution companies had delayed the supply of natural gas to one of our neighbors, we prepared the food for them" (personal interview, April 2016). She also mentioned that her two daughters were rescued by their neighbor. Another woman said: "If the flood destroyed my house, I would go to my son's house who lives right next to me" (personal interview, April 2016). "The other in-depth interviews confirmed that in Koohi-Kheil the familial relationships between neighbors rise in solidarity and mutual aid in times of disaster. 
The results in the Sālār-Zādeh are quite different: Only 17\% of the inhabitants were aware of the needs of their neighbors. We believe that this result could be linked to the urban lifestyle of the inhabitants, the recent construction of new buildings and new settlements. According to the in-depth interviews, the sense of solidarity among Sālār-Zādeh inhabitants is less strong than it is among the inhabitants of Koohi-Kheil. A resident of Sālār-Zādeh, aged 64, said: "At the time of the floods, no one came to my rescue ... because I understand that my neighbors do not have a sense of mutual assistance, I will not help them either" (personal interview, April 2016).

Subsequently, respondents were asked whether they could rely on their acquaintances if necessary. The result was roughly the same in both neighborhoods and the majority of the respondents said that after experiencing flooding they were mostly supported by their relatives. To sum up, family relationships appear to have a considerable influence on neighborhood resilience in the face of a flood.

\section{Self-organization}

The overall results show that self-organization and collective activities are relatively low in both neighborhoods. Although in general, 70\% of the respondents from both neighborhoods emphasized the need for a team spirit between neighbors to prepare for flooding, when they were asked how much time and energy they could devote to helping their neighbors and solving their problems on their own, only $43 \%$ of the interviewees were ready to take responsibility for solving their problems together. Further, they were rather willing to make a contribution to society and its necessary development without financial participation. The comparison of the two neighborhoods shows that the autoorganization indicator is lower in Sālār-Zādeh. The results of the in-depth interviews reveal that the lack of unification between neighbors is an obstacle for collective actions: "If something needs to be done in the neighborhood, everyone should help ... well, I cannot do anything on my own, can I?"(personal interview, April 2016).

Contrary to self-organization, personal and family-based autonomous actions are well practiced in the study areas. A 64-year-old man in Sālār-Zādeh neighborhood said: "It was us ourselves who cleaned up our house. My nephews, other family members and I gathered to get rid of the sludge and waste" (personal interview, April 2016).

\section{Local autonomous innovations}

At first glance, the indicator of autonomous innovation, borrowed from resilient marketing for the purposes of this conceptual research framework, seemed difficult to translate in the questionnaires. The interviewees could not be asked whether they 
thought they were creative in the face of a flood. Hence, we asked them what happened before, during and after the floods. It should be added that this interrogative method is long and consequently requires a great deal of patience. The results show that local residents have used some autonomous innovations to cope with floods. For example, a 77-year-old woman told us how her neighbor, whose house was not touched by the floods, had tied ladders together so that he could reach his home. This idea, which is clearly dangerous, is one of the universal strategies for constructing habitats in floodprone areas: establishing networks of connections between housing units in order to escape flooding. This simple, economic and applicable idea has saved the lives of six people. Another trial-and-error method of reacting to floods was escaping to elevated places. This reaction caused damage in some cases: For example, several inhabitants whose houses were flooded gathered on the wall surrounding the houses. But unlike the houses, the walls, although high, were not made of solid materials. In the end, people have ideas which provide some possible, simple and cheap solutions but if they knew more about floods they would make better use of these ideas.

\section{Conclusions}

This study analyzed the concept of social resilience to floods by considering the following characteristics of the community: Firstly, it is a self-organizing community. Secondly, the inhabitants know and help each other. They like their community and their place of residence and have neighborly relations. In this community, vulnerable inhabitants have identified flood risks and have become capable of preparing themselves against these risks. It is a community with a great sense of cohesion. Thirdly, it is an innovative community with a population that seeks to find and realize simple and cheap local solutions to floods. Its citizens and officials are well informed about floods and help each other. Finally, in this community flood crisis management is based on mutual trust, honesty, justice and egalitarianism.

Given these characteristics, the conceptual framework of our research is structured according to six main criteria of social resilience: (1) place-specific indicators and social vulnerability, (2) public awareness, (3) local autonomous innovations, (4) good governance, (5) self-organization and (6) social capital. These criteria were studied in two different socio-economic neighborhoods (Sālār-Zādeh district and Koohi-Kheil district) of Behshahr, Iran, that are exposed to flood risks. The main points of the conclusion derived from this field study are as follows:

1) Familial relations between neighbors are one of the most important factors in enhancing social resilience. Most rescues and relief interventions during and after flooding were carried out between neighbors who have familial relations, especially in the Koohi-Kheil district. 
2) The Behshahr crisis management focused more on immediate response after the event to normalize the situation. For instance, cleaning the mud from the houses, cleaning the streets, distributing food aid and rescuing lives were among the actions taken by the municipality and the Red Crescent Society in the Sālār-Zādeh district. In other words, no anticipatory intervention to reduce or to control perils were carried out and all actions were taken reactively. Furthermore, in Koohi-Kheil district, there was no action to increase the social capacity of the residents, such as security education and training. In short, social resilience has not been applied yet to the crisis management of Behshahr, and it needs better conceptualization, in-depth knowledge of the criteria and a clear implementation plan in all phases of crisis management.

3) In the transitional area of Sālār-Zādeh, where the morphology of the residential areas varies from houses to apartments, information exchange and public awareness for new inhabitants seems very much needed. The questionnaires showed us that the majority of new inhabitants did not know that their place of residence is exposed to flood hazards.

4) Although social support between neighbors and a sense of belonging to the neighborhood may be influential, they are not correlative. For example, in SālārZàdeh all interviewees stated that they love their neighborhood and want to continue to live there even though there is only little social support between the neighbors. This issue requires more study and sampling.

5) The duration of residence is a crucial element of social resilience. Our results demonstrate that long-term residents know their neighborhood, their neighbors and their needs better than new inhabitants do. In Sālār-Zādeh, which welcomes new inhabitants, the neighbors' needs are not well known. It will therefore be necessary to set up new means of widening and enriching the relationships between neighbors. For example, public spaces and collective activities can foster the means by which neighbors get to know each other and can enrich neighborly relations. As a consequence, they would be better able to help each other and cooperate during or after a flood.

This research, which was carried out for the first time in an area in the southern part of the Caspian Sea, can be considered the beginning of a synthesis and application of the concept of social resilience to floods in urban policies. Our future research will study the traces of these social resilience criteria in the field of urban studies, which focuses on the relationship between urban spaces and social issues. One of our current hypotheses is that establishing more social exchange opportunities in public spaces could affect social capital. This could be yet another step towards the application of the concept of social resilience that is still needed in the urban studies literature. 


\section{References}

Adger W.N., Hughes T.P., Folke C., Carpenter S.R., \& Rockström J. (2005), Social-ecological resilience to coastal disasters. Science 309(5737), pp. 1036-1039.

Adger W.N. (2000), Institutional adaptation to environmental risk under the transition in Vietnam. Annals of the Association of American Geographers 90(4), pp. 738-758.

Ajibade I., McBean G., \& Bezner-Kerr R. (2013), Urban flooding in Lagos, Nigeria: Patterns of vulnerability and resilience among women. Global Environmental Change 23(6), pp. 1714-1725.

Bahadur A., \& Doczi J. (2016), Unlocking resilience through autonomous innovation. Working Paper.

Bahadur A., Ibrahim M., \& TANner T.M. (2013), Characterising resilience: unpacking the concept for tackling climate change and development. Climate and Development 5(1), pp. 55-65.

Barroca B., Dinardo M., \& Mboumoua I. (2013), De la vulnérabilité à la résilience: mutation ou bouleversement? EchoGéo 24. DOI: 10.4000/echogeo.13439

Becker J., McBride S., \& Paton D. (2013), Improving community resilience in the Hawke's Bay: A review of resilience research, and current public education, communication and resilience strategies. GNS Science Report 38.

Becker J.S., Johnston D.M., Daly M.C., Paton D.M., Mamula-Seadon L., Petersen J., Hughes M.E., \& Williams S. (2011), Building community resilience to disasters: A practical guide for the emergency management sector. GNS Science Report 9.

Berke P., \& Godschalk D. (2009), Searching for the good plan: a meta-analysis of plan quality studies. Journal of Planning Literature 23(3), pp. 227-240.

Brooks E., \& Davoudi S. (2013), Evolutionary Resilience and Adaptation to Climate Change in European Coastal Regions. Lecture for Module Town and Country Planning 8932. Planning for Climate Change, Newcastle upon Tyne, UK.

Burby R.J., Deyle R.E., Godschalk D.R., \& Olshansky R.B. (2000), Creating hazard resilient communities through land-use planning. Natural Hazards Review 1(2), pp. 99-106.

Cannon T. (2010), Gender and Climate Hazards in Bangladesh. Gender and Development 10(2), pp. $45-50$.

Carpenter S.R., Westley F., \& Turner G. (2005), Surrogates for resilience of social-ecological systems. Ecosystems 8(8), pp. 941-944.

Chelleri L., \& Olazabal M. (eds.), (2012), Multidisciplinary perspectives on urban resilience: a workshop report. Bilbao, Basque Centre for Climate Change, BC3.

COAFFEE J. (2013), Towards next-generation urban resilience in planning practice: from securitization to integrated place making. Planning Practice \& Research 28(3), pp. 323-339. DOI: $10.1080 / 02697459.2013 .787693$

Colbeau-Justin L. (2002), Stratégies de faire face dans le cas d'une inondation catastrophique: analyse des paramètres psychosociaux dans les procédures de gestion de crise. Programme RIO2, Ministère de l'Ecologie et du Développement Durable, 89.

Cordis.europa.eu (2016), European Commission: CORDIS: Projects \& Results Service: Final Report Summary - CORFU (Collaborative research on flood resilience in urban areas). $\mathrm{http} / / /$ cordis.europa.eu/result/rcn/159320 en.html [Last accessed on 01-11-2017]

Couvent P. (2010), La résilience territoriale, du concept à l'application. Mémoire IAE Lille, pp. 101-110. 
CSI (Centre statistique De L'Iran) (2016), Recensement de la population de la ville de Behshahr, Centre statistique de l'Iran, Tehran.

Cutter S.L., Burton C.G., \& Emrich C.T. (2010) Disaster resilience indicators for benchmarking baseline conditions. Journal of Homeland Security and Emergency Management 7(1), pp. $1-22$.

Cutter S., Boruff B., \& Shirley W. (2003), Social vulnerability to environmental hazards. Social Science Quarterly 84(2), pp. 242-261.

Dauphiné A., \& Provitolo D. (2007), La résilience: un concept pour la gestion des risques. Annales de géographie 654, pp. 115-125.

Davoudi S., Brooks E., \& Menmood A. (2013), Evolutionary Resilience and Strategies for Climate Adaptation. Planning Practice \& Research 28(3), pp. 307-322.

Davoudi S., Shaw K., Haider L., Quinlan A., Peterson G., Wilkinson C., Fünfgeld H., McEvoy D., Porter L., \& Davoudi S. (2012), Resilience: A Bridging Concept or a Dead End? "Reframing" Resilience: Challenges for Planning Theory and Practice Interacting Traps: Resilience Assessment of a Pasture Management System in Northern Afghanistan Urban Resilience: What Does it Mean in Planning Practice? Resilience as a Useful Concept for Climate Change Adaptation? The Politics of Resilience for Planning: A Cautionary Note: Edited by S. Davoudi and L. Porter, Planning Theory \& Practice 13(2), pp. 299-333.

Dемснак C.C. (2006), Embracing surprise in resilient complex critical infrastructures: Rapid crisis response lessons from military organizations and the Atrium model. Paper presented at the SEMA/ECMA Conference, Stockholm, Sweden.

Enemark C. (2006), Pandemic pending. Australian Journal of International Affairs 60, pp. 43-49.

Folke C., Carpenter S., Walker B., Scheffer M., Chapin T., \& Rockstrom J. (2010), Resilience thinking: Integrating resilience, adaptability and transformability. Ecology and Society 15(4), pp. 20-28.

Forgette R., \& Boening M. (2009), Measuring and Modeling Community Resilience: SERP and DyME, US Department of Homeland Security, USA.

Frank E., EAKIN H., \& Lopez-CARr D. (2011), Social identity, perception and motivation in adaptation to climate risk in the coffee sector of Chiapas, Mexico. Global Environmental Change 21(1), pp. 66-76.

Frazier T.G., Thompson C.M., Dezzani R.J., \& Butsick D. (2013), Spatial and temporal quantification of resilience at the community scale. Applied Geography 42, pp. 95-107.

Friend R., Jarvie J., Reed S., Sutarto R., Thinphanga P., \& Toan V.C. (2014), Mainstreaming urban climate resilience into policy and planning; reflections from Asia. Urban Climate 7, pp. 6-19.

GaLLopin G.C. (2006), Linkages between vulnerability, resilience and adaptive capacity. Global Environmental Change 16, pp. 293-303.

González-Riancho P., Gerkensmeier B., Ratter B.M.W., González M., \& Medina R. (2015), Storm surge risk perception and resilience: A pilot study in the German North Sea coast. Ocean \& Coastal Management 112, pp. 44-60.

Gupta A. K. (2013), Tapping the entrepreneurial potential of grassroots innovation. Stanford Social Innovation Review. http://ssir.org/articles/entry [Last accessed on 01-11-2017]

Harland L., Harrison W., Jones J.R., \& Reiter-Palmon R. (2005), Leadership behaviors and subordinate resilience. Journal of Leadership Organizational Studies 11, pp. 2-14.

Hegney D., Ross H., \& BaKer P. (2008), Building resilience in rural communities: tool kit. 
Hopkins A. (2005), Safety, Culture and Risk. Sydney, CCH Australia Limited.

Jha A., Bloch R., \& Lamond J. (2012), Cities and flooding: A guide to integrated urban flood risk management for the $21^{\text {st }}$ century. Washington, DC, GFDRR/World Bank.

Jha A.K., Miner T.W., \& Stanton-Geddes Z. (2013), Building Urban Resilience: Principles, Tools, and Practice. Washington, DC, The World Bank.

Jun H.J., Conroy M.M. (2014), Linking resilience and sustainability in Ohio township planning. Journal of Environmental Planning and Management (SSCI) 57(6), pp. 904-919.

Kaniasty K., \& Norris F. (1999), The Experience of Disaster: Individuals and Communities Sharing Trauma, Response Disaster: Psychosocial, Community, and Ecological Approaches. Philadelphia, PA, Brunner/Mazel, pp. 25-61.

KeCK M., \& SAKDAPOLRAK P. (2013), What is social resilience? Lessons learned and ways forward. Erdkunde 67(1), pp. 5-19.

Khalili S., Harre M., \& Morley P. (2015), A temporal framework of social resilience indicators of communities to flood, case studies: Wagga wagga and Kempsey, NSW, Australia. International Journal of Disaster Risk Reduction 13, pp. 248-254.

Kotzee I., \& Reyers B. (2016), Piloting a social-ecological index for measuring flood resilience: A composite index approach. Ecological Indicators 60, pp. 45-53.

LALONDE C. (2011), Managing crises through organizational development: a conceptual framework. Disasters 35(2), pp. 443-464.

Legas A. (2016), Qualities of Effective Leadership and Its impact on Good Governance. http:// www.abyssinialaw.com/blog-posts/item/1473-qualities-of-effective-leadership-and-itsimpact-on-good-governance [Last accessed on 28-09-2016]

Lhome S., Serre D., Diaby Y., \& Laganier R. (2010), Résilience urbaine et réseaux techniques: une approche par l'analyse spatiale pour une évaluation possible de la résilience urbaine. Séminaire "Résilience urbaine", ENS, Paris. http://www.geographie.ens.fr/IMG/file/ resilience/pres-ens.pdf [Last accessed on 01-11-2017]

Lo A. Y., Xu B., Chan F.K.S., \& Su R. (2015), Social Capital and Community Preparation for Urban Flooding in China. Applied Geography 64, pp. 1-11.

Lutoff C., Creutin J., Ruin I., \& Borga M. (2016), Anticipating flash-floods: Multi-scale aspects of the social response. Journal of Hydrology 541(A), pp. 626-635. DOI: 10.1016/j. jhydrol.2016.01.005

Maclean K., Cuthill M., \& Ross H. (2013), Six attributes of social resilience. Journal of Environmental Planning and Management 57(1), pp. 144-156. DOI: 10.1080/09640568.2013.763774

MEDDE. (2012), Risque Inondation: quels défis pour la recherche en appui à l'action publique?

Miller M., Paton D., \& Johnston D. (1999), Community vulnerability to volcanic hazard consequences. Disaster Preventive Management 8, pp. 255-260.

Mitchell T., \& Harris K. (2012), Resilience: A risk management approach. Background Note. London, Overseas Development Institute. https://www.odi.org/sites/odi.org.uk/files/odiassets/publications-opinion-files/7552.pdf [Last accessed on 01-11-2017]

Moore S., Daniel M., Linnan L., Campbell M., Benedict S., \& Meier A. (2004), After Hurricane Floyd passed: investigating the social determinants of disaster preparedness and recovery. Family Community Health 27, pp. 204-217.

MurpHY B.L. (2007), Locating social capital in resilient community-level emergency management. Natural Hazards 41(2), pp. 297-315. 
Mustafa D. (1998), Structural causes of vulnerability to flood hazard in Pakistan. Economic Geography 74(3), pp. 289-305.

NaKagawa Y., \& Shaw R. (2004), Social capital: a missing link to disaster recovery. International Journal of Mass Emergency Disasters 22, pp. 5-34.

Paton D. (2010), Adaptive capacity/resilience model: Summary of PGSF research. Wellington, Joint Centre for Disaster Research, Massey University.

Paton D., Millar M., \& Johnston D. (2001), Community resilience to volcanic hazard consequences. National Hazards 24, pp. 157-169.

Pelling M., \& High C. (2005), Understanding adaptation: What can social capital offer assessments of adaptive capacity? Global Environmental Change 15, pp. 308-319.

BDNRP (Behshahr's Distressed Neighborhoods Renovation Project) (2016), Haftshahr Aria consulting engineers, Iran. Document No.1.

Quenault B. (2014), La rhétorique de la résilience dans la gestion des risques de catastrophe: vers un changement de paradigme? Colloque international 2Pau "Pratiques et portée de l'adaptation: enjeux territoriaux ambivalents de la régulation environnementale", organisé par le laboratoire SET, Université de Pau, 23-24 janvier 2014.

Ratter B.M.W., \& Gee K. (2012), Heimat - a German concept of regional perception and identity as a basis for coastal management in the Wadden Sea. Ocean Coastal Management 68, pp. 127-137.

Reisi M., Aye L., Rajabifard A., \& NGo T. (2014), Transport sustainability index: Melbourne case study. Ecological Indicators 43, pp. 288-296.

Robert J. (2012), Pour une géographie de la gestion de crise: de l'accessibilité aux soins d'urgence à la vulnérabilité du territoire à Lima. University of Grenoble (diss.).

Rose A. (2007), Economic resilience to natural and man-made disasters: Multidisciplinary origins and contextual dimensions. Environmental Hazards 7(4), pp. 383-398.

Roussy S. (2013), Renforcer la résilience aux chocs et aux stress. ACF-International, Document d'Information 15.

Sato T. (2006), Fundamental Characteristics of Flood Risk in Japan's Urban Areas. In: Ikeda S., FukUzono T., \& SATo T. (eds.), A better integrated management of disaster risks: Toward resilient society to emerging disaster risks in mega-cities. Tokyo, TERRAPUB and NIED, pp. 23-40.

Schelfaut K., Pannemans B., van der Craats I., Krywkow J., Mysiak J., \& Cools J. (2011), Bringing flood resilience into practice: the FREEMAN project. Environmental Science \& Policy 14, pp. 825-833.

Simmie J., \& Martin R. (2010), The economic resilience of regions: Towards an evolutionary approach. Cambridge Journal of Regions, Economy and Society 3(1), pp. 27-43.

Smit B., \& WANDEL J. (2006), Adaptation, adaptive capacity and vulnerability. Global Environmental Change 16, pp. 282-292.

Swanstrom T. (2008), Regional resilience: A critical examination of the ecological framework. IURD Working Paper Series, Berkeley, CA, Institute of Urban and Regional Development, UC Berkeley.

TERI (2011), Mainstreaming Urban Resilience Planning in Indian Cities: A Policy Perspective. TERI-Rockefeller Foundation, New Delhi.

ToBIN G.A. (1999), Sustainability and community resilience: the holy grail of hazards planning? Global Environment Change, Part B: Environment Hazards 1, pp. 13-25. 
TRAChSLer D. (2009), La résilience: un concept pour la gestion des catastrophes et crises. Politique de sécurité. Center for Security Studies, Zurich, pp. 60, 1-3.

Turner B.L., Kasperson R.E., Matson P.A., McCarthy J.J., Corell R.W., Christensen L., Eckley N., Kasperson J.X., Luers A., Martello M.L., Polsky C., Pulsipher A., \& Schiller A. (2003), A framework for vulnerability analysis in sustainability science. Proceedings of the National Academy of Sciences in the United States of America 100(14), pp. 8074-8079.

Turner R.A., Addison J., Arias A., Bergseth B.J., Marshall N.A., Morrison T.H., \& Tobin R. C. (2016), Trust, confidence, and equity affect the legitimacy of natural resource governance. Ecology and Society 21(3), pp. 18. DOI: 10.5751/ES-08542-210318

UNESCAP (United Nations Economic and Social Commission for Asia and the Pacific) (2009), What is Good Governance? www.unescap.org/resources/what-good-governance [Last accessed 05-04-2018]

UNiSDR (United Nations International Strategy for Disaster Reduction) (2004), Guidelines for Reducing Flood Losses. Geneva, UNISDR.

UNiSDR (United Nations International Strategy for Disaster Reduction) (2013), Making cities resilient: Summary for policymakers. A global snapshot of how local governments reduce disaster risk. Geneva, UNISDR.

WHO (World Health Organization) (2010), Monitoring the building blocks of health systems: A handbook of indicators and their measurement strategies. www.who.int/healthinfo/ statistics/toolkit_hss/en/index.html [Last accessed on 05-04-2018]

Yasmin Z.K., Marwa A.K., \& Aly N.E. (2016), Comparative Study of Community Resilience in Mega Coastal Cities Threatened by Sea Level Rise: The Case of Alexandria and Jakarta Procedia. Social and Behavioral Sciences 216, pp. 503-517.

Zaninetti J.-M., NGo A.T., \& Grivel S. (2013), La construction sociale de la vulnérabilité face au risque d'inondation au Viêt Nam. Revue Mappemonde online 114. http://mappemonde. mgm.fr/num42/articles/art14202.html [Last accessed on 05-04-2018]

\section{Figure and Table}

Figure 1: Two flood-prone neighborhoods in the city of Behshahr 139

Table 1: Social resilience framework 


\section{ISR-Forschungsberichte}

1 Zoltán CséFalvay und Walter Rohn (1991): Der Weg des ungarischen Arbeitsmarktes in die duale Ökonomie

2 Elisabeth Lichtenberger (Hg., 1991): Die Zukunft von Ostmitteleuropa. Vom Plan zum Markt

3 Marlies Schulz (1991): Der Tauschwohnungsmarkt in der zentralistischen Planwirtschaft - das Beispiel von Ostberlin

4 Helga Sснмірт (1991): Die metropolitane Region Leipzig - Erbe der sozialistischen Planwirtschaft und Zukunftschancen

5 Hugo PenZ (1992): Entwicklungsstruktur und Zukunft von ländlicher Siedlung und Landwirtschaft in der ČSFR und in Ungarn

6 Zoltán CséFalvay und Walter RoHn (1992): Die Transition des ungarischen und Budapester Wohnungsmarktes

7 Alina MuzioŁ-WęCŁawowicz (unter Mitarbeit v. Josef Kohlbacher, 1992):

Die Transformation des Wohnungswesens in Polen - eine Analyse des Warschauer Wohnungsmarktes

8 Grzegorz WęcŁawowicz (unter Mitarbeit v. Josef Kohlbacher, 1993): Die sozialräumliche Struktur Warschaus - Ausgangslage und postkommunistische Umgestaltung

9 Markus SeIDL (1993): Stadtverfall in Bratislava

10 Heinz Fassmann, Josef Kohlbacher und Ursula Reeger (1993): „Suche Arbeit“ - Eine empirische Analyse über Stellensuchende aus dem Ausland

11 Heinz Fassmann, Zoltán CSÉFAlvaY und Walter RoHn (1993): Regionalstruktur im Wandel - Das Beispiel Ungarn

12 Ursula BAUER (1994): Europa der Regionen - Zwischen Anspruch und Wirklichkeit

13 Heinz Fassmann, Josef Kohlbacher und Ursula Reeger (1995): Die „neue Zuwanderung" aus Ostmitteleuropa - Eine empirische Analyse am Beispiel der Polen in Österreich

14 Heinz Fassmann (Hg., 1995): Immobilien-, Wohnungs- und Kapitalmärkte in Ostmitteleuropa. Beiträge zur regionalen Transformationsforschung

15 Heinz Fassmann und Christiane Hintermann (1997): Migrationspotential Ostmitteleuropa. Struktur und Motivation potentieller Migranten aus Polen, der Slowakei, Tschechien und Ungarn

16 Heike JöNS und Britta KLAGGE (1997): Bankwesen und Regionalstruktur in Ungarn

17 Konrad SCHERF (1998): Die metropolitane Region Berlin. Genese und Niedergang, Revitalisierung und Innovation 
18 Heinz Fassmann, Christiane Hintermann, Josef Kohlbacher und Ursula REEGER (1999): „Arbeitsmarkt Mitteleuropa“. Die Rückkehr historischer Migrationsmuster

19 Zoltán Cséfalvay (1999): Die Wettbewerbsfähigkeit der österreichischen Großstädte. Theoretische Ansätze und empirische Befunde

20 Axel Borsdorf und Michaela PaAl (Hg., 2000): Die „alpine Stadt“ zwischen lokaler Verankerung und globaler Vernetzung. Beiträge zur regionalen Stadtforschung im Alpenraum

21 Walter RонN (2000): Forschungseinrichtungen in der Agglomeration Wien. Stellung im Innovationsprozeß und Einbindung in innovative Netzwerke

22 Vera MAYER (2000): Regionale Innovationspotentiale und innovative Netzwerke der Industrieunternehmen in der metropolitanen Region Wien. Ergebnisse einer Unternehmensbefragung

23 Axel Borsdorf (Hg., 2000): Perspectives of Geographical Research on Latin America for the 21st Century

24 Wolfgang Berger (2001): Photovoltaics in Europe in the Year 2020. Utilities, Sustainable Development and Culture

25 Heinz Fassmann, Josef Kohlbacher und Ursula Reeger (in Zusammenarbeit mit Katharina Demel und Irene STACHER, 2001): Integration durch berufliche Mobilität? Eine empirische Analyse der beruflichen Mobilität ausländischer Arbeitskräfte in Wien

26 Walter RoHN (2002): Regelung versus Nichtregelung internationaler Kommunikationsbeziehungen. Das Beispiel der UNESCO-Kommunikationspolitik

27 Vera MAYer (2002): Wohnpräferenzen von Jugendlichen in Wien. Ein Beitrag zur Kultur und Sozialgeographie des Wohnens

28 Michael Janoschka (2002): Wohlstand hinter Mauern. Private Urbanisierungen in Buenos Aires

29 Axel Borsdorf und Christof PARnReiter (Hg., 2003): International Research on Metropolises - Milestones and Frontiers

30 Heinz Fassmann, Josef Kohlbacher und Ursula Reeger (2004): Polen in Wien. Entwicklung, Strukturmerkmale und Interaktionsmuster

31 Josef Kohlbacher und Ursula Reeger (2005): Aus aller Herren Länder? Wien als Studienort und internationale Bildungsmetropole

32 Josef Kohlbacher und Ursula ReEger (2006): „Gespanntes Nachbarschaftsverhältnis?" Eine empirische Analyse des interethnischen Zusammenlebens in unterschiedlichen Wohnbaukategorien in Wien

33 Josef Kohlbacher und Ursula Reeger (2006): Die Dynamik ethnischer Wohnviertel in Wien. Eine sozialräumliche Longitudinalanalyse 1981 und 2005 
34 Wolfgang Bosswick, Heinz Fassmann, Josef Kohlbacher and Doris LÜKEN-KLASSEn (2007): Housing and Residential Segregation of Migrants. A state-of-the-art report

35 Josef Kohlbacher und Ursula Reeger (2008): Staatsbürgerschaftsbonus beim Wohnen? Eine emprische Analyse der Unterschiede zwischen eingebürgerten und nichteingebürgerten Zuwanderern/-innen hinsichtlich ihrer Wohnsituation in Wien

36 Heinz Fassmann and Yvonne Franz (Hg., 2010): Integration Policies on the Local Level: Housing Policies for Migrants. Examples from New York City, St. Paul, Antwerp, Vienna and Stuttgart

37 Josef Kohlbacher, Ursula Reeger and Philipp Schnell (2012): Neighbourhood Embeddedness and Social Coexistence. Immigrants and Natives in Three Urban Settings in Vienna

38 Peter Jordan (Hg., 2012): Regional Development and Regionalisation in the Adriatic Space. Proceedings of the 3rd Conference of the Adriatic Forum, Vienna, September 23-25 2010

39 Josef Kohlbacher und Ursula Reeger (2013): Von der Nische ins Zentrum? Unternehmer mit türkischem oder exjugoslawischem Migrationshintergrund in der Wiener Wirtschaft

40 Robert Musil und Jakob Eder (2013): Wien und seine Hochschulen. Regionale Wertschöpfungsefekte der Wiener Hochschulen

41 Robert Musil und Jakob Eder (2015): Local Buzz in der Wiener Forschung. Wissensintensive Cluster zwischen lokaler Einbettung und internationaler Orientierung

42 Peter Jordan (Hg., 2017): 10 Years of EU Eastern Enlargement - The Geographical Balance of a Courageous Step. Proceedings of the Symposion in Vienna, 3-4 December 2014

43 Peter Jordan (Hg., 2017): New Developments in the Rural Space of Central and SouthEast Europe - Proceedings of the meeting of the Working Group on Central Europe in conjunction with the German Congress of Geography, Berlin, September 30, 2015

44 Yvonne Franz and Christiane Hintermann (Hg., 2017): Unravelling Complexities. Understanding Public Spaces

45 Josef Kohlbacher and Leonardo Schioccet (Hg., 2017): From Destination to Integration Afghan, Syrian and Iraqi refugees in Vienna

46 Julia Dahlvik, Yvonne Franz, Myrte Hoekstra and Josef Kohlbacher (Hg., 2017): Interethnic Coexistence in European Cities. A policy handbook 
